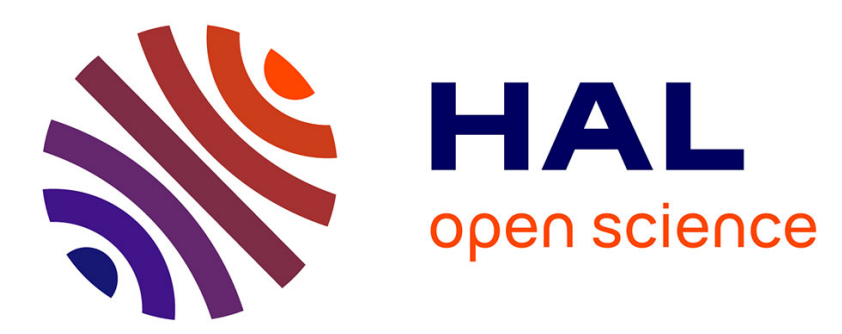

\title{
Preparation of LTA, HS and FAU/EMT intergrowth zeolites from aluminum scraps and industrial metasilicate
}

\author{
Rahma Abid, G. Delahay, Hassib Tounsi
}

\section{- To cite this version:}

Rahma Abid, G. Delahay, Hassib Tounsi. Preparation of LTA, HS and FAU/EMT intergrowth zeolites from aluminum scraps and industrial metasilicate. Journal of Material Cycles and Waste Management, 2019, 21 (5), pp.1188-1196. 10.1007/s10163-019-00873-x . hal-02273090

\section{HAL Id: hal-02273090 \\ https://hal.science/hal-02273090}

Submitted on 26 Nov 2020

HAL is a multi-disciplinary open access archive for the deposit and dissemination of scientific research documents, whether they are published or not. The documents may come from teaching and research institutions in France or abroad, or from public or private research centers.
L'archive ouverte pluridisciplinaire HAL, est destinée au dépôt et à la diffusion de documents scientifiques de niveau recherche, publiés ou non, émanant des établissements d'enseignement et de recherche français ou étrangers, des laboratoires publics ou privés. 


\title{
Preparation of LTA, HS and FAU/EMT intergrowth zeolites from aluminum scraps and industrial metasilicate
}

\author{
Rahma Abid ${ }^{1}$, Gérard Delahay ${ }^{2}$, Hassib Tounsi ${ }^{1, *}$ \\ ${ }^{1}$ Laboratoire des matériaux avancés, Ecole Nationale d'Ingénieurs de Sfax, Université de Sfax, TUNISIE. \\ ${ }^{2}$ Institut Charles Gerhardt, CNRS/UM/ENSCM, Equipe "Matériaux Avancés pour la Catalyse et la Santé", \\ Ecole Nationale Supérieure de Chimie de Montpellier, 240 av. du Professeur Emile Jeanbrau, 34296 Montpellier \\ cedex, FRANCE.
}

*Corresponding author: hassibtounsi@yahoo.fr

\begin{abstract}
Na-LTA zeolite crystals were synthesized via hydrothermal method using aluminum scraps and industrial sodium metasilicate. The obtained hydrogel with molar composition: 3,741 $\mathrm{Na}_{2} \mathrm{O}: \mathrm{Al}_{2} \mathrm{O}_{3}: 1.450 \mathrm{SiO}_{2}: 175.520 \mathrm{H}_{2} \mathrm{O}$ was aged at room temperature for 14 hours and heated at $80^{\circ} \mathrm{C}$ for 6 hours. The use of aluminum scraps provides well crystallized cubic NaLTA zeolites with truncated edges and apexes. When $\mathrm{H}_{2} \mathrm{O} / \mathrm{Al}_{2} \mathrm{O}_{3}$ molar ratio was decreased: 3.741 $\mathrm{Na}_{2} \mathrm{O}: \mathrm{Al}_{2} \mathrm{O}_{3}: 1.450 \mathrm{SiO}_{2}: 92.50 \mathrm{H}_{2} \mathrm{O}$ there is formation of an intergrowth of FAU/EMT phases contaminated with LTA zeolite after $6 \mathrm{~h}$ of crystallization. The prolongation of the crystallization time to 48 hours leads the formation of hydoxysodalite zeolite. On the other hand, the increase of aging time to 96 hours, the crystal sizes of zeolite decrease.
\end{abstract}

Keywords: Aluminum scraps, Sodium metasilicate, Zeolite LTA, Intergrowth FAU/EMT, Hydrothermal synthesis

\section{Introduction}

The use of aluminum has a good interest in the industrial sector, but it produces a large amount of waste which is harmful to the environment and human health. This waste inhibits root growth, which in turn affects the ability of the plant to adsorb water and nutrients [1]. Also exposure to aluminum can affect health, including nervous system, Alzheimer disease and other neurodegenerative disorders [2]. For that, many researchers have been focused in the recycling aluminum waste to product materials. Abdelkader et al [3] Used waste 
aluminum beverage cans for the preparation of mesoporous gamma alumina by a simple precipitation method using two different precipitating agents $(\mathrm{NaOH}$ or $\mathrm{NH} 4 \mathrm{OH})$.Jraba et al [4] valorize aluminum chips into $\gamma-\mathrm{Al}_{2} \mathrm{O}_{3}$ and $\eta-\mathrm{Al}_{2} \mathrm{O}_{3}$ by acidic precipitation of sodium aluminate obtained via an alkaline attack of the scraps. M. Selim et al.[5] reported the preparation of LTA zeolite from aluminum scrubs and commercial sodium silicate solution at $110^{\circ} \mathrm{C}$ for $8 \mathrm{~h}$. Tounsi et al [6] prepared zeolite Na-LTA, NaX and HS from Tunisian sand and aluminum scraps. Furthermore, Abdelrahman [7] used waste aluminum cans to prepare different zeolites (LTA, ANA, SOD, and NaP1) via a low-cost hydrothermal method. R. Sánchez-Hernández et al. [8] prepared $\mathrm{NaP} 1$ zeolite from Al-containing waste from metallurgical industry by recycling the effluents with zero liquid discharge. A. Meshram et al [9] used aluminum dross to synthesis zeolite FAU type X.

Zeolites are crystallized inorganic solids characterized by a 3-D framework constituted via the arrangement of tetrahedral units $\left[\mathrm{SiO}_{4}\right]^{4-}$ and $\left[\mathrm{AlO}_{4}\right]^{5-}$ linked by their oxygen atoms $[10$, 11]. The assembly of these tetrahedral units leads to the formation of large microporous networks consisting of channels and cages distributed periodically in space. Negative charges carried by $\left[\mathrm{AlO}_{4}\right]^{-}$tetrahedra are compensated generally by alkaline $\left(\mathrm{Na}^{+}, \mathrm{K}^{+} \ldots\right)$ and alkaline earth metal cations $\left(\mathrm{Ca}^{2+}, \mathrm{Mg}^{2+} \ldots\right)$. These cations are surrounded with water molecules and are located in the cavities and channels of the zeolite framework [11, 12]. Due to their fascinating properties i.e. physical and hydrothermal stabilities, high surface areas [13], non-toxicity, framework and compositional flexibilities, zeolites found applications in many fields. Thus, zeolites found applications in the fields of ion exchange, adsorption, catalysis, separation and molecular sieves [14]. On the other hand, nanosized zeolites were used in innovative applications like holographic sensors, medicine and photovoltaic $[15,16]$. Among all synthetic zeolites, the Na-LTA is the most produced and used in the industry. It is largely used for the formulation of phosphorus free detergents as water softener and for alkane/alkene 
separation [17]. Na-LTA has a pore diameter of $4 \AA$, which can be modified either to $5 \AA$ or 3 Å by ion exchange with calcium or potassium, respectively.

Zeolites are generally synthesized under hydrothermal conditions using an aluminosilicate gel in the presence of a mineralizing agent $\left(\mathrm{OH}^{-}, \mathrm{F}^{-}\right)$in an aqueous solution. The aluminosilicate gel is heated in an autoclave from a few hours to several days at temperature between ambient and $200^{\circ} \mathrm{C}$ under autogenous pressure $[10,18]$. The hydrothermal synthesis of zeolites usually used expensive materials such as silica, alumina chemical sources and structure directing agents [19]. So when the chemical composition or sources of reagent were modified they cause the formation of a different kind of zeolite[20]. Therefore, inexpensive preparations have been reported in literature using industrial wastes. Chen et al [21] prepared zeolite $\mathrm{NaX}$ and $\mathrm{NaA}$ from coal mining solid waste, coal gangue, by alkali fusion followed by hydrothermal treatment. Zhang et al [22] utilized iron ore tailing for the synthesis of zeolite A by hydrothermal method. Khoshbin and Karimzadeh [23] succeeded to prepare free template nanostructured ZSM-5 zeolite from rice husk ash using ultrasound radiation. Maatoug et al. [24] prepared Na-X, Na-P, SOD and EMT/FAU zeotype materials using vitreous China waste by conventional hydrothermal route and alkaline fusion prior to hydrothermal synthesis. Also G. Garcia et al. study the effect of $\mathrm{NaCl}$ on the selective synthesis of FAU-zeolites from diatomite [25]. On the other hand, inexpensive preparations of zeolites derived from low-cost geological materials have been reported in the literature [2629]. In this study we investigated the valorization of aluminum scraps into LTA, HS and FAU/EMT intergrowth zeolites using industrial sodium metasilicate as silicon source. The starting hydrogel with the following molar composition "3.741 $\mathrm{Na}_{2} \mathrm{O}: \mathbf{A l}_{\mathbf{2}} \mathrm{O}_{3}: 1.450$ $\mathrm{SiO}_{2}: \mathbf{1 7 5 . 5 2 0} \mathrm{H}_{2} \mathrm{O}$ " was prepared. Others sources of aluminum were also tested for the sake of comparison. Furthermore, the influence of aging time and $\mathrm{H}_{2} \mathrm{O} / \mathrm{Al}_{2} \mathrm{O}$ molar ratios were also investigated. 


\section{Materials and Methods}

\subsection{Materials}

Sodium metasilicate $\left(\mathrm{Na}_{2} \mathrm{SiO}_{3} .5 \mathrm{H}_{2} \mathrm{O}\right.$, PQ CORPORATION) was used as silicon source in the preparation of LTA zeolites. The conventional aluminum sources were aluminum nitrate ( $\mathrm{Al}\left(\mathrm{NO}_{3}\right) \cdot 9 \mathrm{H}_{2} \mathrm{O}$, MERCK 95\%), aluminum chloride $\left(\mathrm{AlCl}_{3} \cdot 6 \mathrm{H}_{2} \mathrm{O}\right.$, FLUKA $\left.99 \%\right)$ aluminum powder, synthesis grade (SCHARLAU 99\%), aluminum sulfate LR $\left(\mathrm{Al}_{2}\left(\mathrm{SO}_{4}\right)_{3} \cdot 16 \mathrm{H}_{2} \mathrm{O}\right.$, SUVCHEM 98 \%). The aluminum scraps was collected from metal manufacturing industry in the region of Sfax; South-eastern of Tunisia which has the following composition (Al (wt. \%) $=99.77 \pm 0.02 ; \mathrm{Fe}($ wt. \%) $=0.207 \pm 0.006$ and $\mathrm{Cu}$ wt. $\%)=0.008 \pm 0.001)$. Sodium hydroxide pellets (NaOH, SIGMA ALDRICH 99\%) were used as mineralizing agent.

\subsection{Synthesis of zeolite Na-LTA}

Firstly, we dissolved the $\mathrm{NaOH}$ pellets in the required quantity of distilled water. Then we divided the solution to equal volumes in polypropylene bottles. The desired quantity of aluminum scraps (aluminum powder) was dissolved in one half of hydroxide solution volume and then filtered to remove the impurities. Sodium metasilicate was added to the $\mathrm{NaOH}$ solution and mixed in capped bottle until clear. Aluminum nitrate, aluminum chloride, and aluminum sulfate sources were dissolved in distilled water. In order to obtain the aluminosilicate hydrogel, the silicon solution was poured to the aluminum solution quickly. The obtained thickly gel was stirred during a period of $10 \mathrm{~min}$ and then was aged for $14 \mathrm{~h}$ at room temperature (RT). Finally, the aged gel was heated at $80^{\circ} \mathrm{C}$ for $6 \mathrm{~h}$. After the crystallization was achieved, the obtained solids were filtered, washed with distilled water until $\mathrm{pH}$ around 9 , and then dried at $80^{\circ} \mathrm{C}$ for $24 \mathrm{~h}$.

It should be noted that the final molar composition of the gel used for the preparation of LTA zeolite is $\left(3.741 \mathrm{Na}_{2} \mathrm{O}: \mathrm{Al}_{2} \mathrm{O}_{3}: 1.450 \mathrm{SiO}_{2}: 175.520 \mathrm{H}_{2} \mathrm{O}\right.$ [30]) which is the sequential 
optimization by the simplex method of the standard composition of Thomson and Franklin (3.165 $\mathrm{Na}_{2} \mathrm{O}: \mathrm{Al}_{2} \mathrm{O}_{3}: 1.926 \mathrm{SiO}_{2}: 128 \mathrm{H}_{2} \mathrm{O}$ [31]) to obtain $95.4 \%$ of relative crystallinity.

In order to determine the specific area of the prepared Na-LTA, $\mathrm{Na}^{+}$cations were exchanged with $\mathrm{Ca}^{2+}$ and $\mathrm{NH}_{4}{ }^{+}$. The exchange was carried out at $\mathrm{RT}$ by stirring $6 \mathrm{~g}$ of the parent Na-LTA zeolite in $250 \mathrm{~mL}$ of $0.5 \mathrm{M} \mathrm{CaCl}_{2} \cdot 2 \mathrm{H}_{2} \mathrm{O}$ or $0.5 \mathrm{M} \mathrm{NH} \mathrm{NCl}_{4}$ solutions for $24 \mathrm{~h}$. The suspensions were filtered and rinsed with distilled water to remove excess of adsorbed species and then dried at $100^{\circ} \mathrm{C}$ for $24 \mathrm{~h}$.

\subsection{Characterizations and analyses}

The samples obtained were characterized by a variety of conventional techniques. Powder Xray diffraction (XRD) patterns were obtained using D8 ADVANCE BRUKER $40 \mathrm{Kv}$ with $\mathrm{Cu}$ $\mathrm{K} \alpha$ radiation. The diffraction pattern was collected in the $2 \theta$ range of $5-50^{\circ}$ at a scan speed of 0.02. The crystallinity $\mathrm{C}(\%)$ of the prepared samples was estimated by XRD analysis using commercial zeolite Na-LTA (VALFOR ${ }^{\circledR}$ 100) as standard (Eq. 1). The method consists of comparing the total of six current selected peaks in the angular range 15-30 in $2 \theta$ as imposed by the standard test method for the determination of relative crystallinity of zeolite Na-LTA (ASTM D5357-03).

$$
\% \text { Crystallinity }=\frac{\sum \text { Intensity of XRD peaks of product }}{\sum \text { Intensity of XRD peaks of standard }} \times 100
$$

IR spectra were recorded by a Perkin-Elmer FTIR spectrometer with a resolution of $4 \mathrm{~cm}^{-1}$ using $\mathrm{KBr}$ method. The scanning electron microscopy (SEM) images were taken on a Hitachi S 4800 operated at $5 \mathrm{kV}$. Some samples were analyzed using Energy-dispersive X-ray spectroscopy on AZTEC-EDS apparatus. Nitrogen sorption experiments were carried out at $196^{\circ} \mathrm{C}$ on a micrometrics ASAP 2020 after degassing the sample at $250^{\circ} \mathrm{C}$. The micropore volume $\left(\mathrm{V}_{\text {micro }}\right)$ and external area $\left(\mathrm{S}_{\text {ext }}\right)$ were determined by the plot method micrometrics 
Tristar Surface Area and Porosity analyzer. The BET surface areas $\left(\mathrm{S}_{\mathrm{BET}}\right)$ and pore size distributions were determined by nitrogen adsorption-desorption on an ASAP2020 instrument (Micromeritics Instrument Corporation, GA), the pore size distributions were calculated by the advanced Barrett-Joyner-Halenda (BJH) method using the adsorption-desorption branches of the isotherms. Prior to these measurements, the samples were degassed at $250{ }^{\circ} \mathrm{C}$ in vacuum.

\section{Results and discussions}

\subsection{Effect of aluminum sources}

To investigate the influence of aluminum sources, several preparations have been studied by varying the aluminum precursors; aluminum scraps $\left(\mathrm{Z}_{\mathrm{NaA} . \mathrm{Sc}} 6 \mathrm{~h}-80\right)$, aluminum powder $\left(Z_{\text {NaA.P } 6 h-80}\right)$, aluminum nitrate $\left(Z_{\text {NaA.N } 6 h-80}\right)$, aluminum chloride $\left(Z_{\text {NaA.C 6h-80 }}\right)$ and aluminum sulfate $\left(Z_{\text {NaA.S }} 6 \mathrm{~h}-80\right)$. The obtained hydrogels with final molar compositions of “3.741 $\mathrm{Na}_{2} \mathrm{O}: \mathrm{Al}_{2} \mathrm{O}_{3}: 1.450 \mathrm{SiO}_{2}: 175.520 \mathrm{H}_{2} \mathrm{O}$ ” were aged $14 \mathrm{~h}$ at $\mathrm{RT}$ and then were crystallized at $80^{\circ} \mathrm{C}$ for $6 \mathrm{~h}$. From figure 1 , one can see that aluminum scraps $\left(\mathrm{Z}_{\mathrm{NaA} . S c 6 \mathrm{~h}-80}\right)$ and aluminum powder $\left(\mathrm{Z}_{\mathrm{NaA} . \mathrm{P} 6 \mathrm{~h}-80}\right)$ provide well crystallized Na-LTA zeolite $\left(\left|\mathrm{Na}_{94.75}\left(\mathrm{H}_{2} \mathrm{O}\right)_{39.17}\right|\left[\mathrm{Si}_{96} \mathrm{Al}_{96} \mathrm{O}_{384}\right]\right.$ (ICDD No.01-089-8015) [32]. On the other hand, the use of nitrate $\left(Z_{\text {NaA.N } 6 h-80}\right)$, chloride $\left(Z_{\text {NaA.C } 6 h-80}\right)$ and sulfate $\left(Z_{\text {NaA.S } 6 h-80}\right)$ aluminum precursors leads to amorphous solids. Despite, the prolongation of the crystallization time to $12 \mathrm{~h}$ of the aluminosilicate gels prepared from nitrate, chloride, and sulfate, only amorphous materials were obtained. It seems that the increase of the reaction time does not initiate the germination stage to achieve the growth and crystallization of LTA zeolite. Bosnar et al. [33] showed that the presence of inorganic anions $\left(\mathrm{NO}^{3-}, \mathrm{SO}_{4}{ }^{2-}, \mathrm{Cl}^{-}\right)$slows down the germination and crystallization processes by increasing the steric and electrostatic interactions between the inorganic anions and the aluminosilicate anions. 
It should be mentioned that the zeolites prepared from aluminum powder and aluminum scraps have slightly enhanced relative crystallinities than the commercial one.

On the other hand, the chemical analysis performed by EDS technique on different spots of the surface of $\mathrm{Z}_{\mathrm{NaA} . S c} 6 \mathrm{~h}-80, \mathrm{Z}_{\mathrm{CaA} . S c} 6 \mathrm{~h}-80$ and $\mathrm{Z}_{\mathrm{NH} 4 \mathrm{~A} . S c 6 \mathrm{~h}-80}$ samples are reported in Table 1. Figure 2 showed the XRD patterns of the $Z_{\mathrm{NaA} . S c} 6 \mathrm{~h}-80$ exchanged with calcium $\left(Z_{\mathrm{Ca}-}\right.$ A.Sc 6h-80) and ammonium $\left(\mathrm{Z}_{\mathrm{NH} 4-\mathrm{A} . \mathrm{Sc} 6 \mathrm{~h}-80}\right)$. The structure of the parent zeolite Na-LTA does not change after the introduction of $\mathrm{Ca}^{2+}$ and $\mathrm{NH}_{4}{ }^{+}$in exchange sites. Indeed, the XRD profiles of $\mathrm{Z}_{\mathrm{NH} 4-\mathrm{A} . \mathrm{Sc}} 6 \mathrm{~h}-80$ and $\mathrm{Z}_{\mathrm{Ca}-\mathrm{A} . \mathrm{Sc}} 6 \mathrm{~h}-80$ samples showed fine lines characteristic of LTA zeolites.

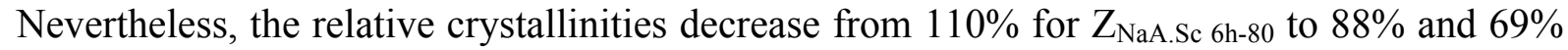
for $Z_{\text {NH4A.Sc6h-80 }}$ and $Z_{\text {Ca-A.Sc 6h-80, }}$, respectively. Price and al.[34] showed that the exchange with $\mathrm{NH}_{4}{ }^{+}$ions compromises some of the long-range order of the zeolite LTA crystals due to the loss of some framework aluminum. Whereas, no alteration to the long-range crystal order is observed when divalent $\mathrm{Ca}^{2+}$ ions was exchanged. In our case, we think that the good crystallinity of $\mathrm{Z}_{\mathrm{NH} 4 \mathrm{~A} . \mathrm{Sc} 6 \mathrm{~h}-80}$ compared to $\mathrm{Z}_{\mathrm{Ca}-\mathrm{A} . \mathrm{Sc} 6 \mathrm{~h}-80}$, is due to the $\mathrm{NH}_{4}{ }^{+}$partial exchange in sample $\mathrm{Z}_{\mathrm{NH} 4 \mathrm{~A} . \mathrm{Sc} 6 \mathrm{~h}-80}$. Indeed, the remaining sodium cations in $\mathrm{Z}_{\mathrm{NH4A.Sc6h-80}}$ sample are about 7.16 wt. \% whereas they are about 1.68 wt. $\%$ for $\mathrm{Z}_{\text {Ca-A.Sc } 6 \mathrm{~h}-80}$.

The SEM micrographs of $\mathrm{Z}_{\mathrm{NaA} . S c} 6 \mathrm{~h}-80, \mathrm{Z}_{\mathrm{Ca}-\mathrm{A} . S c} 6 \mathrm{~h}-80$ and $\mathrm{Z}_{\mathrm{NH} 4 \mathrm{~A} . S c 6 h-80}$ were displayed in figure 3. The presence of cubic crystals with truncated edges and apexes with an average diameter less than $1 \mu \mathrm{m}$ attested the formation of LTA zeolite type. Some crystals presented twinned morphology which is rather common in natural and synthetic zeolites. It is the result of mirror plane that occurs inside the structure. The twinning phenomenon in LTA zeolite is the result of a rotation along threefold axis [111] at an angle of $180^{\circ}$ [35]. It was shown that crystal twinning could stabilize a crystal polymorph that is otherwise not the most stable form [36]. 
According to Kosanovic et al [37], zeolite LTA crystals have four particular morphologies $i$ ) regular cubic crystal with sharp edges and apexes when $2 \leq \mathrm{SiO}_{2} / \mathrm{Al}_{2} \mathrm{O}_{3} \leq 2.2$ and $\mathrm{Na}_{2} \mathrm{O} / \mathrm{H}_{2} \mathrm{O} \leq 0.0136$, ii) cubic crystals with truncated edges when $\mathrm{SiO}_{2} / \mathrm{Al}_{2} \mathrm{O}_{3} \leq 2.2$ and $0.0136 \leq \mathrm{Na}_{2} \mathrm{O} / \mathrm{H}_{2} \mathrm{O} \leq 0.0162$, iii) cubic crystals with rounded edges and apexes when 1.3 $\leq \mathrm{SiO}_{2} / \mathrm{Al}_{2} \mathrm{O}_{3} \leq 2$ and $0.016 \leq \mathrm{Na}_{2} \mathrm{O} / \mathrm{H}_{2} \mathrm{O} \leq 0.024$ and iv) pseudo-spherical obtained when $\mathrm{SiO}_{2} / \mathrm{Al}_{2} \mathrm{O}_{3} \leq 1.3$ and $\mathrm{Na}_{2} \mathrm{O} / \mathrm{H}_{2} \mathrm{O} \geq 0.037$. In our case, we obtained cubic crystal with truncated edges (molar ratio $\mathrm{SiO}_{2} / \mathrm{Al}_{2} \mathrm{O}_{3}=1.45$ and $\mathrm{Na}_{2} \mathrm{O} / \mathrm{H}_{2} \mathrm{O}=0.021$ ). A high alkalinity of the reaction mixture contributes to a high supersaturation which leads to a high surface nucleation and the formation of cubic crystal with rounded edges and apexes [37].

On the other hand, Kosanovic et al. [37] suggested that the formation of cubic crystals with truncated edges (formation of $\{011\}$ crystal faces) was a result of the decrease of crystal growth in this direction caused by distortion of terminal $\mathrm{SiO}_{4}$ tetrahedrons, positioned at crystal edges and apexes, in the presence of excess of aluminate ions.

The introduction of $\mathrm{Ca}^{2+}$ and $\mathrm{NH}_{4}^{+}$into the Na-LTA zeolite is accompanied by noticeable changes in the surface morphology, as shown in figure 3. The cubic automorphism of the original zeolite-LTA was not destroyed, but its surface morphology was completely changed from the original smooth surface.

Figure 4 presents the nitrogen adsorption-desorption isotherms of the samples $Z_{\mathrm{NaA} . S \mathrm{c}}$

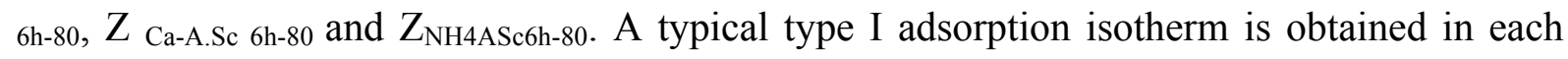
case, indicating that the solids are microporous. At very low relative pressures $\left(\mathrm{p} / \mathrm{p}^{\circ}=0.02\right)$, there is a steep in the nitrogen uptake attributed to the filling of micropores. The presence of hysteresis loop from 0.45 to 0.95 arises from the packing of zeolite nanocrystals [38]. The low $\mathrm{S}_{\mathrm{BET}}=10.8 \mathrm{~m}^{2} / \mathrm{g}$ value of zeolite Na-LTA is due to the limited zeolite channel size $(\Phi=4.2$ $\AA$ ) preventing access to nitrogen molecules $(\Phi=4.54 \AA)$. So, the measured $\mathrm{S}_{\mathrm{BET}}$ corresponds to the external surface of the sample. According to Breck et al [10] the presence of $\mathrm{Na}^{+}$ 
cations near octagonal openings prevents the diffusion of nitrogen molecules. The exchange of Na-LTA with $\mathrm{Ca}^{2+}$ cations modified the pore diameter of zeolite from $4 \AA$ to $3 \AA$ which increased the $\mathrm{S}_{\mathrm{BET}}$ from $10.8 \mathrm{~m}^{2} / \mathrm{g}$ to $=550.0 \mathrm{~m}^{2} / \mathrm{g}$.

\subsection{Crystallization kinetic of zeolite LTA at $80^{\circ} \mathrm{C}$}

Figure 5 shows the XRD patterns of the zeolites obtained at different crystallization times from 1 to 6 hours at $80^{\circ} \mathrm{C}$ using aluminum scraps and sodium metasilicate. All samples were aged for $14 \mathrm{~h}$ at RT before crystallization. After 1 hour of crystallization, the sample $\left(\mathrm{Z}_{\mathrm{NaA} . S c 1 \mathrm{~h}}\right.$

${ }_{80}$ ) is still amorphous. After 2 hours, fine peaks characteristic of the LTA zeolite appear and increase in intensity up to 6 hours. From the results in figure 5, the optimal crystallization time of the zeolite LTA is 6 hours where the crystallinity is about $113 \%$.

\subsection{Effect of aging time}

The effect of aging time on the obtained products was also investigated. All samples were hydrothermally crystallized for $6 \mathrm{~h}$ at $80^{\circ} \mathrm{C}$ after an aging time at $\mathrm{RT}$ for $0 \mathrm{~h}(\mathrm{Z}-0 \mathrm{~h}), 24 \mathrm{~h}$ (Z-24h); $48 \mathrm{~h}(\mathrm{Z}-48 \mathrm{~h}) ; 72 \mathrm{~h}(\mathrm{Z}-72 \mathrm{~h})$ and $96 \mathrm{~h}$ (Z-96h). The XRD patterns in figure 6 reveal that all products leads to zeolite Na-LTA, with relative crystallinities equals to $92.6 \%, 96.3 \%$, $80.2 \%, 101.2 \%$ and $85.2 \%$ for aging times of $0 \mathrm{~h}, 24 \mathrm{~h}, 48 \mathrm{~h}, 72 \mathrm{~h}$ and $96 \mathrm{~h}$, respectively.

The SEM micrographs of the obtained samples aged at different times are displayed in figure 7. The SEM results confirm the synthesis of zeolite LTA with the presence of truncated cubic crystals. For the no aged sample $\mathrm{Z}-\mathrm{Oh}$, the crystallization is not completed and one can see amorphous gel between the cubic crystals of LTA zeolite. We note that when the aging time increases the size of the crystals decreases. This can be explained by the fact that at longer aging time, there is formation of more pre-nuclei [39]. In general, aging at low temperature promotes nucleation process and increases the number of nuclei in the synthesis 
system because it offers the time required to achieve the formation of nuclei, which leads to the formation of smaller crystals [40, 41].

\subsection{Effect of $\mathrm{H}_{2} \mathrm{O} / \mathrm{Al}_{2} \mathrm{O}_{3}$ molar ratio}

To investigate the influence of $\mathrm{H}_{2} \mathrm{O} / \mathrm{Al}_{2} \mathrm{O}_{3}$ molar ratio on the nature of obtained products, four hydrogel compositions have been prepared:

$>\mathbf{Z}_{\text {ASc 6h-80 }}: 3,741 \mathrm{Na}_{2} \mathrm{O}: \mathrm{Al}_{2} \mathrm{O}_{3}: 1.450 \mathrm{SiO}_{2}: 175.52 \mathrm{H}_{2} \mathrm{O}$

$>\mathbf{Z}_{\mathbf{A . S c 6 h 8 0} ; \mathbf{H 2 O} / 2}: 3,741 \mathrm{Na}_{2} \mathrm{O}: \mathrm{Al}_{2} \mathrm{O}_{3}: 1,450 \mathrm{SiO}_{2}: 92.50 \mathrm{H}_{2} \mathrm{O}$

Z $\mathbf{Z}_{\text {A.Sc6h80; }}$ H2Ox2 $_{3}: 3,741 \mathrm{Na}_{2} \mathrm{O}: \mathrm{Al}_{2} \mathrm{O}_{3}: 1,450 \mathrm{SiO}_{2}: 341.51 \mathrm{H}_{2} \mathrm{O}$,

$\mathbf{Z}_{\mathbf{A} . \mathbf{S c 6 h 8 0}}{ }_{\mathrm{H} 20 \mathbf{3} 3}: 3,741 \mathrm{Na}_{2} \mathrm{O}: \mathrm{Al}_{2} \mathrm{O}_{3}: 1,450 \mathrm{SiO}_{2}: 507.51 \mathrm{H}_{2} \mathrm{O}$

As can be seen in figure $\mathbf{8}$, the increase of water quantity does not favors the

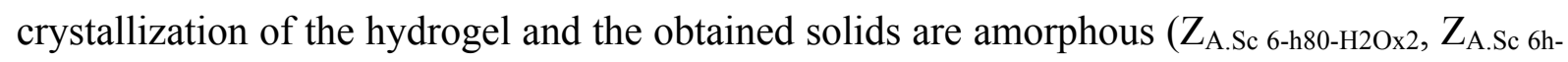
80- $\mathrm{H} 2 \mathrm{O} \times 3)$. It is established that with the increase of water quantity, there is a decrease of the alkalinity of the system. The dilution diminishes the Si and Al primary units' concentrations which slows the nucleation process. On the other hand, the decrease of the $\mathrm{H}_{2} \mathrm{O} / \mathrm{Al}_{2} \mathrm{O}_{3}$ molar ratio $\left(\mathrm{Z}_{\mathrm{A} . \mathrm{Sc} 6 \mathrm{~h}-80-\mathrm{H} 2 \mathrm{O} / 2}\right)$ leads to the formation of an intergrowth of FAU/EMT contaminated with LTA zeolite. The XRD pattern shows broad peaks which confirmed the ultra-small sized zeolite particles. It is established that FAU ([ $\left.\mathrm{Na}_{2} \mathrm{Al}_{2} \mathrm{Si}_{4} 8 \mathrm{H}_{2} \mathrm{O}\right]$ (ICDD No.00-039-1380) and EMT ([Na $\mathrm{Na}_{19.36}\left(\mathrm{Al}_{22.27} \mathrm{Si}_{73.73} \mathrm{O}_{192}\right)$ (ICDD No. 00-046-0566)) zeolites exhibit a strong tendency to form coherent intergrowth since they are constructed from the same building units. EMT is the structural twin of FAU, i.e. both are composed of D6R connected sodalite cages, but the location of connections is different, resulting in cubic FAU and hexagonal EMT structure, respectively [42-44].

On the other hand, the kinetic study of the crystallization of the gel composition: $\mathbf{3 . 7 4 1}$ $\mathrm{Na}_{2} \mathrm{O}: \mathrm{Al}_{2} \mathrm{O}_{3}: 1.450 \mathrm{SiO}_{2}: 92.50 \mathrm{H}_{2} \mathrm{O}\left(\mathrm{Z}_{\mathrm{A} . \mathrm{Sc} 6 \mathrm{~h} 80 ; \mathrm{H} 2 \mathrm{O} / 2}\right)$ was realized at $80{ }^{\circ} \mathrm{C}$ from 6 to $48 \mathrm{~h}$ 
(figure 9). As shown before, the XRD profile of the hydrogel after $6 \mathrm{~h}$ of crystallization showed FAU/EMT intergrowth contaminated with LTA zeolite. With the increase of crystallization time to $12 \mathrm{~h}$, LTA zeolite became the abundant phase. The further prolongation

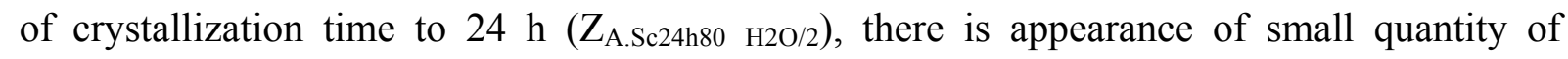
hydroxysodalite (HS) zeolite $\left(\left|\mathrm{Na}_{8}\left(\mathrm{H}_{2} \mathrm{O}\right)_{8}\right|\left[\mathrm{Si}_{6} \mathrm{Al}_{6} \mathrm{O}_{24}\right]\right.$ ICDD No.11-0401) besides LTA and FAU/EM. After $48 \mathrm{~h}$ of crystallization $\left(\mathrm{Z}_{\mathrm{A} . \mathrm{Sc}} 48 \mathrm{~h}-80 \mathrm{H} 2 \mathrm{O} / 2\right)$, the product contains mainly $\mathrm{HS}$ zeolite. From these results, one can conclude that the transformation of the metastable phase (zeolite Na-LTA) to more thermodynamically stable phase zeolite HS at longer reaction time, illustrated Oswald's rule of successive transformations. The nucleation and crystallization of the new phase occur in the supersaturated solution throughout the dissolution of the former phase [45]. On the other hand, it is well known that zeolite formation is a kinetically controlled process and the reaction is generally stopped when the desired zeolite has formed. Extended reaction time at high temperatures and/or high pressures usually results in dense phases.

\section{Concluding remarks}

In this study, zeolites type LTA, EMT/FAU intergrowth and HS have been prepared using cheap starting materials; aluminum scraps and industrial sodium metasilicate. The optimized hydrogel molar composition 3,741 $\mathrm{Na}_{2} \mathrm{O}: \mathrm{Al}_{2} \mathrm{O}_{3}: \mathbf{1 , 4 5 0} \mathrm{SiO}_{2}: \mathbf{1 7 5 , 5 2 0} \mathrm{H}_{2} \mathrm{O}$ which leads to LTA zeolite has been used. It was shown that aluminum scraps and aluminum powder provide well crystallized Na-LTA zeolites with truncated edges and apexes after hydrothermal treatment at $80^{\circ} \mathrm{C}$ for $6 \mathrm{~h}$. On the other hand, nitrate, chloride and sulfate aluminum precursors lead to amorphous solids. When the water quantity was decreased (3.741 $\mathbf{N a}_{2} \mathbf{O}: \mathbf{A l}_{2} \mathbf{O}_{3}: \mathbf{1 . 4 5 0}$ $\mathrm{SiO}_{2}: 92.50 \mathrm{H}_{2} \mathrm{O}$ ) there is formation of an intergrowth of FAU/EMT phases contaminated with LTA zeolite after $6 \mathrm{~h}$ of crystallization. The prolongation of the crystallization time to 48 hours leads to the formation of the hydoxysodalite zeolite. 


\section{References}

[1] S. K. Panda, (2015) Aluminum Stress Adaptation in Plants. Switzerland Springer.

[2] Niu, Q. in (2018) Neurotoxicity of Aluminum 1-31 Springer.

[3] A. Abdelkader, A.I. Osman, S.A. Halawy, M.A. Mohamed (2018) Preparation and characterization of mesoporous $\gamma$-Al $2 \mathrm{O} 3$ recovered from aluminum cans waste and its use in the dehydration of methanol to dimethyl ether, J. Mater. Cycles Waste Manag. 1-9.

[4] Jraba, N., Tounsi, H. \& Makhlouf, T.(2016) Valorization of Aluminum Chips into $\gamma$ A12O3and $\eta-A 12 O 3 w i t h$ High Surface Areas via the Precipitation Route. Waste and Biomass Valorization 9, 1003-1014.

[5] Selim, M. M., EL-Mekkawi, D. M., Aboelenin, R. M. M., Sayed Ahmed, S. A. \& Mohamed, G. M. (2017) Preparation and characterization of Na-A zeolite from aluminum scrub and commercial sodium silicate for the removal of $\mathrm{Cd} 2+$ from water. J. Assoc. Arab Univ. Basic Appl. Sci. 24, 19-25.

[6] Tounsi, H., Mseddi, S. \& Djemel, S. (2009) Preparation and characterization of Na-LTA zeolite from Tunisian sand and aluminum scrap. Phys. Procedia 2, 1065-1074.

[7] Abdelrahman, E. A. (2018) Synthesis of zeolite nanostructures from waste aluminum cans for efficient removal of malachite green dye from aqueous media. J. Mol. Liq. 253, 72-82.

[8] Sánchez-Hernández, R., Padilla, I., López-Andrés, S. \& López-Delgado (2017). A. Ecofriendly bench-scale zeolitization of an Al-containing waste into gismondine-type zeolite under effluent recycling. J. Clean. Prod. 161, 792-802.

[9] Meshram, A. \& Singh, K. K. (2018) Recovery of valuable products from hazardous aluminum dross: A review. Resour. Conserv. Recycl. 130, 95-108.

[10] BRECK \& W., D. (1974) Ion exchange reactions in zeolites. Zeolite Mol. Sieves Struct. Chem. Use.

[11] Ali, I. O., El-Sheikh, S. M., Salama, T. M., Bakr, M. F. \& Fodial, M. H. (2015) Controllable synthesis of $\mathrm{NaP}$ zeolite and its application in calcium adsorption. Sci. China Mater. 58, 621-633. 
[12] Xu, R., Pang, W., Yu, J., Huo, Q. \& Chen, J. (2009) Chemistry of zeolites and related porous materials: synthesis and structure, John Wiley \& Sons.

[13] Wang, G. et al. (2015) Zeolite-zeolite composite fabricated by polycrystalline y zeolite crystals parasitizing ZSM-5 zeolite. J. Mater. Res. 30, 2434-2446.

[14] Koohsaryan, E. \& Anbia, M. (2016) Nanosized and hierarchical zeolites: A short review. Cuihua Xuebao/Chinese J. Catal. 37, 447-467.

[15] Zaarour, M., Dong, B., Naydenova, I., Retoux, R. \& Mintova, S. (2014) Progress in zeolite synthesis promotes advanced applications. Microporous Mesoporous Mater. 189, 1121.

[16] Rabo, J. A. \& Schoonover, M. W. (2001) Early discoveries in zeolite chemistry and catalysis at Union Carbide, and follow-up in industrial catalysis. Appl. Catal. A Gen. 222, 261-275.

[17] Granato, M. A., Vlugt, T. J. H. \& Rodrigues, A. E. (2007) Molecular simulation of propane- propylene binary adsorption equilibrium in zeolite 4A. Ind. Eng. Chem. Res. 46, $321-328$.

[18] Drioli, E. Encyclopedia of Membranes. (2016). doi:10.1007/978-3-662-44324-8.

[19] Cundy, C. S. \& Cox, P. A. (2005) The hydrothermal synthesis of zeolites: Precursors, intermediates and reaction mechanism. Microporous Mesoporous Mater. 82, 1-78.

[20] Oonkhanond, B. \& Mullins, M. E. (2004) The effect of composition on the growth and morphology of zeolite A in solution. J. Mater. Res. 19, 1613-1622.

[21] Chen, J. \& Lu, X. (2018) Synthesis and characterization of zeolites NaA and NaX from coal gangue. J. Mater. Cycles Waste Manag. 20, 489-495.

[22] Zhang, C. \& Li, S. (2018) Utilization of iron ore tailing for the synthesis of zeolite A by hydrothermal method. J. Mater. Cycles Waste Manag. 20, 1605-1614.

[23] Khoshbin, R. \& Karimzadeh, R. (2017) Synthesis of mesoporous ZSM-5 from rice husk ash with ultrasound assisted alkali-treatment method used in catalytic cracking of light naphtha. Adv. Powder Technol. 28, 1888-1897.

[24] Maatoug, N., Delahay, G. \& Tounsi, H. (2018) Valorization of vitreous China waste to EMT/FAU, FAU and Na-P zeotype materials. Waste Manag. 74, 267-278.

[25] Garcia, G., Cabrera, S., Hedlund, J. \& Mouzon, J. (2018) Selective synthesis of FAUtype zeolites. J. Cryst. Growth 489, 36-41.

[26] Abdullahi, T., Harun, Z. \& Othman, M. H. D. (2017) A review on sustainable synthesis 
of zeolite from kaolinite resources via hydrothermal process. Adv. Powder Technol. 28, $1827-1840$.

[27] Bortolatto, L. B. et al. (2017) Synthesis and characterization of Y zeolites from alternative silicon and aluminium sources. Microporous Mesoporous Mater. 248, 214 221.

[28] Belviso, C. (2018) State-of-the-art applications of fly ash from coal and biomass: A focus on zeolite synthesis processes and issues. Prog. Energy Combust. Sci. 65, 109-135.

[29] Kunecki, P., Panek, R., Wdowin, M. \& Franus, W. (2017) Synthesis of faujasite (FAU) and tschernichite (LTA) type zeolites as a potential direction of the development of lime Class C fly ash. Int. J. Miner. Process. 166, 69-78.

[30] García-Soto, A. R., Rodríguez-Niño, G. \& Trujillo, C. A. (2013) Zeolite LTA synthesis : Optimising synthesis conditions by using the modified sequential simplex method. Ing. e Investig. 33, 22-27.

[31] Thompson, R. \& Franklin, K. (2003) Synthesis of Zeolite LTA. Zeolites 11, 577.

[32] Treacy, M. M. J. \& Higgins, J. B. (2007) Collection of simulated XRD powder patterns for zeolites fifth (5th) revised edition. Elsevier.

[33] Bosnar, S., Antonić-Jelić, T., Bronić, J., Krznarić, I. \& Subotić, B. (2004) Influence of anions on the kinetics of zeolite A crystallization: A population balance analysis. $J$. Cryst. Growth 267, 270-282.

[34] Price, L., Leung, K. \& Sartbaeva, A. (2017) Local and Average Structural Changes in Zeolite A upon Ion Exchange. Magnetochemistry 3, 42.

[35] Porcher, F., Dusausoy, Y., Souhassou, M. \& Lecomte, C. (2000) Epitaxial growth of zeolite X on zeolite A and twinning in zeolite A: structural and topological analysis. Mineral. Mag. 64, 1-8.

[36] Davey, R. J. et al. (1993) Stabilization of a metastable crystalline phase by twinning. Nature 366, 248-250.

[37] Kosanović, C., Jelić, T. A., Bronić, J., Kralj, D. \& Subotić, B. (2011) Chemically controlled particulate properties of zeolites: Towards the face-less particles of zeolite A. Part 1. Influence of the batch molar ratio [SiO2/A12O3]b on the size and shape of zeolite A crystals. Microporous Mesoporous Mater. 137, 72-82.

[38] Bendenia, S., Marouf-Khelifa, K., Batonneau-Gener, I., Derriche, Z. \& Khelifa, A. (2011) Adsorptive properties of $\mathrm{X}$ zeolites modified by transition metal scation exchange. Adsorption 17, 361-370.

[39] Nibou, D., Mekatel, H., Amokrane, S., Barkat, M. \& Trari, M. (2010) Adsorption of 
$\mathrm{Zn} 2+$ ions onto $\mathrm{NaA}$ and $\mathrm{NaX}$ zeolites: Kinetic, equilibrium and thermodynamic studies. J. Hazard. Mater. 173, 637-646.

[40] Huang, Y. et al. (2010) Synthesis of hierarchical porous zeolite NaY particles with controllable particle sizes. Microporous Mesoporous Mater. 127, 167-175.

[41] Valtchev, V. P. \& Bozhilov, K. N. (2004) Transmission Electron Microscopy Study of the Formation of FAU-Type Zeolite at Room Temperature. J. Phys. Chem. B 108, $15587-15598$.

[42] Belviso, C. (2016) EMT-type zeolite synthesized from obsidian. Microporous Mesoporous Mater. 226, 325-330.

[43] Inayat, A., Schneider, C. \& Schwieger, W. (2015) Organic-free synthesis of layer-like FAU-type zeolites. Chem. Commun. 51, 279-281.

[44] Khaleel, M., Wagner, A. J., Mkhoyan, K. A. \& Tsapatsis, M. (2014) On the rotational intergrowth of hierarchical FAU/EMT zeolites. Angew. Chemie - Int. Ed. 53, 94569461.

[45] E, H. (2017) Synthesis of Phase-Pure Zeolite Sodalite from Clear Solution Extracted from Coal Fly Ash. J. Thermodyn. Catal. 8. 


\section{Table captions}

Table 1: Chemical analysis, BET surface area $\left(\mathrm{S}_{\mathrm{BET}}\right)$ and microporous volume $(\mu \mathrm{V})$ of $\mathrm{Z}_{\mathrm{NaA} . S c 6 \mathrm{~h}-80,} \mathrm{Z}_{\mathrm{CaA} . S c 6 h-80}$ and $\mathrm{Z}_{\mathrm{NH} 4 \mathrm{~A} . \mathrm{Sc} 6 \mathrm{~h}-80}$ samples. 
Table 1 : Chemical analysis, BET surface area $\left(\mathrm{S}_{\mathrm{BET}}\right)$ and microporous volume $(\mu \mathrm{V})$ of $\mathrm{Z}_{\mathrm{NaA} . S c} 6 \mathrm{~h}-80, \mathrm{Z}_{\mathrm{CaA} . S c} 6 \mathrm{~h}-80$ and $\mathrm{Z}_{\mathrm{NH} 4 \mathrm{~A} . S c 6 \mathrm{~h}-80}$ samples.

\begin{tabular}{|c|c|c|c|c|c|c|c|}
\hline Samples & Si (wt. \%) & Al (wt. \%) & Na (at. \%) & Ca (wt. \%) & $\begin{array}{c}\mathrm{Si} / \mathrm{Al} \\
(\mathrm{mol} / \mathrm{mol})\end{array}$ & $\begin{array}{c}\mathrm{S}_{\mathrm{BET}} \\
\left(\mathrm{m}^{2} / \mathrm{g}\right)\end{array}$ & $\begin{array}{c}\mu V \\
\left(\mathrm{~cm}^{3} / \mathrm{g}\right)\end{array}$ \\
\hline${ }_{\mathrm{NaA} . S c 6 h-80}$ & $45.74 \pm 0.90$ & $37.30 \pm 0.98$ & $16.96 \pm 1.75$ & - & $1.187 \pm 0.010$ & 10.8 & 0.0026 \\
\hline LaA.Sc6h-80 & $39.05 \pm 1.21$ & $32.67 \pm 0.53$ & $1.68 \pm 0.16$ & $26.60 \pm 1.70$ & $1.148 \pm 0.020$ & 550.0 & 0.2337 \\
\hline JH4A.Sc6h-80 & $52.24 \pm 0.56$ & $40.60 \pm 0.15$ & $7.16 \pm 0.63$ & & $1.236 \pm 0.010$ & 85.9 & 0.0275 \\
\hline
\end{tabular}




\section{Figure captions}

Figure 1: XRD of samples obtained from different sources of aluminum at $80^{\circ} \mathrm{C}$ for $6 \mathrm{~h}$ : $\mathrm{Z}_{\mathrm{NaA} . \mathrm{Sc}}$ 6h-80 (aluminum scraps), $\mathrm{Z}_{\mathrm{NaA} . \mathrm{P}}$ 6h-80 (aluminum powder), $\mathrm{Z}$ NaA.N 6 h-80 (aluminum nitrate), $\mathrm{Z}_{\mathrm{NaA} . \mathrm{C} 6 \mathrm{~h}-80}$ (aluminum chloride), and $\mathrm{Z}_{\mathrm{NaA.S} \text { 6h-80 }}$ (aluminum sulfate).

Figure 2: $\mathrm{XRD}$ of samples $\mathrm{Z}_{\mathrm{NaA} . S c} 6 \mathrm{~h}-80, \mathrm{Z}_{\mathrm{Ca}-\mathrm{A} . \mathrm{Sc} 6 \mathrm{~h}-80}$ and $\mathrm{Z}_{\mathrm{NH} 4 \mathrm{~A} . \mathrm{Sc} 6 \mathrm{~h}-80}$

Figure 3: SEM micrographs of zeolites (A) Z. NaA.Sc 6h-80, (B) $Z_{\text {CaA.Sc } 6 h-80}$ and (C) $Z_{\text {NH4A.Sc6h-80 }}$

Figure 4: $\mathrm{N}_{2}$ adsorption-desorption isotherms of $\mathrm{Z}_{\mathrm{NaA} . \mathrm{Sc} 6 \mathrm{~h}-80,} \mathrm{Z}_{\mathrm{CaA}-\mathrm{Sc} 6 \mathrm{~h}-80}$ and $\mathrm{Z}_{\mathrm{NH} 4 \mathrm{ASc}}$ 6h-80 zeolites

Figure 5: XRD profiles of zeolites LTA crystallized at $80^{\circ} \mathrm{C}$ at different times.

Figure 6: XRD patterns of LTA zeolites obtained by hydrothermal method at different aging time.

Figure 7: SEM micropgraphs of samples aged at different times Z-0h (A), Z-48h (B) and Z96h (C).

Figure 82 : XRD patterns of variation molar ratio $\mathrm{H}_{2} \mathrm{O} / \mathrm{Al}_{2} \mathrm{O}_{3} ; \mathrm{Z}_{\mathrm{NaA} . S c} 6 \mathrm{~h}-80 \mathrm{H} 2 \mathrm{O} / 2, \mathrm{Z}_{\mathrm{NaA} . S c} 6 \mathrm{~h}-80^{-}$ $\mathrm{H} 2 \mathrm{O} \times 2$; and $\mathrm{Z}_{\mathrm{NaA} . S c} 6 \mathrm{~h}-80-\mathrm{H} 2 \mathrm{O} \times 3$ for $6 \mathrm{~h}$ at $80^{\circ} \mathrm{C}$

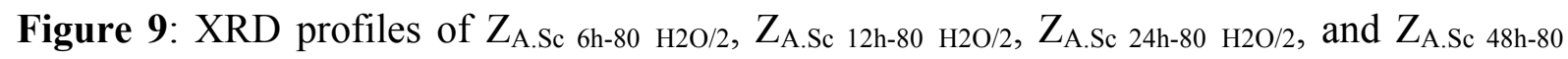
$\mathrm{H} 2 \mathrm{O} / 2$ samples. 
Figure 1

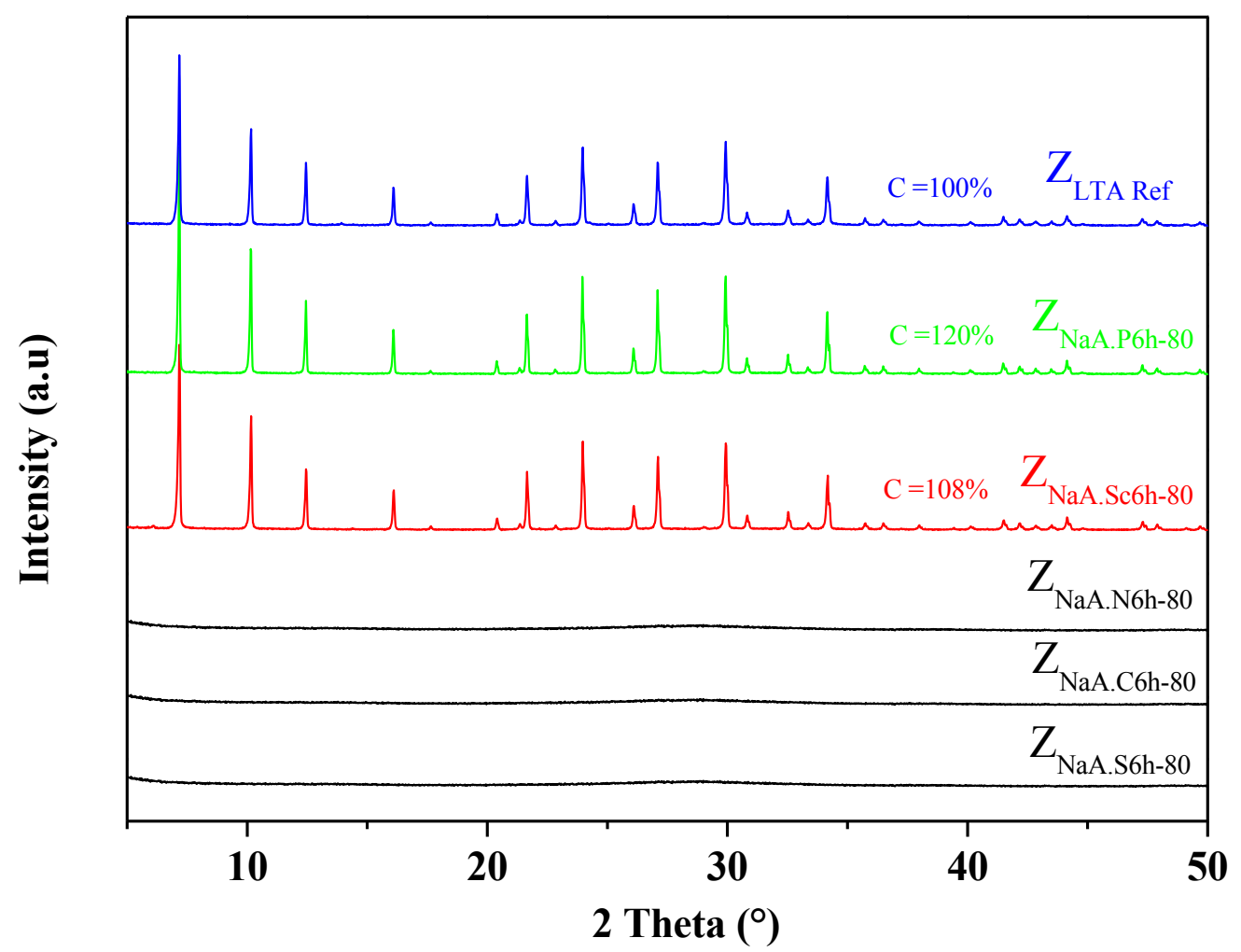


Figure 2

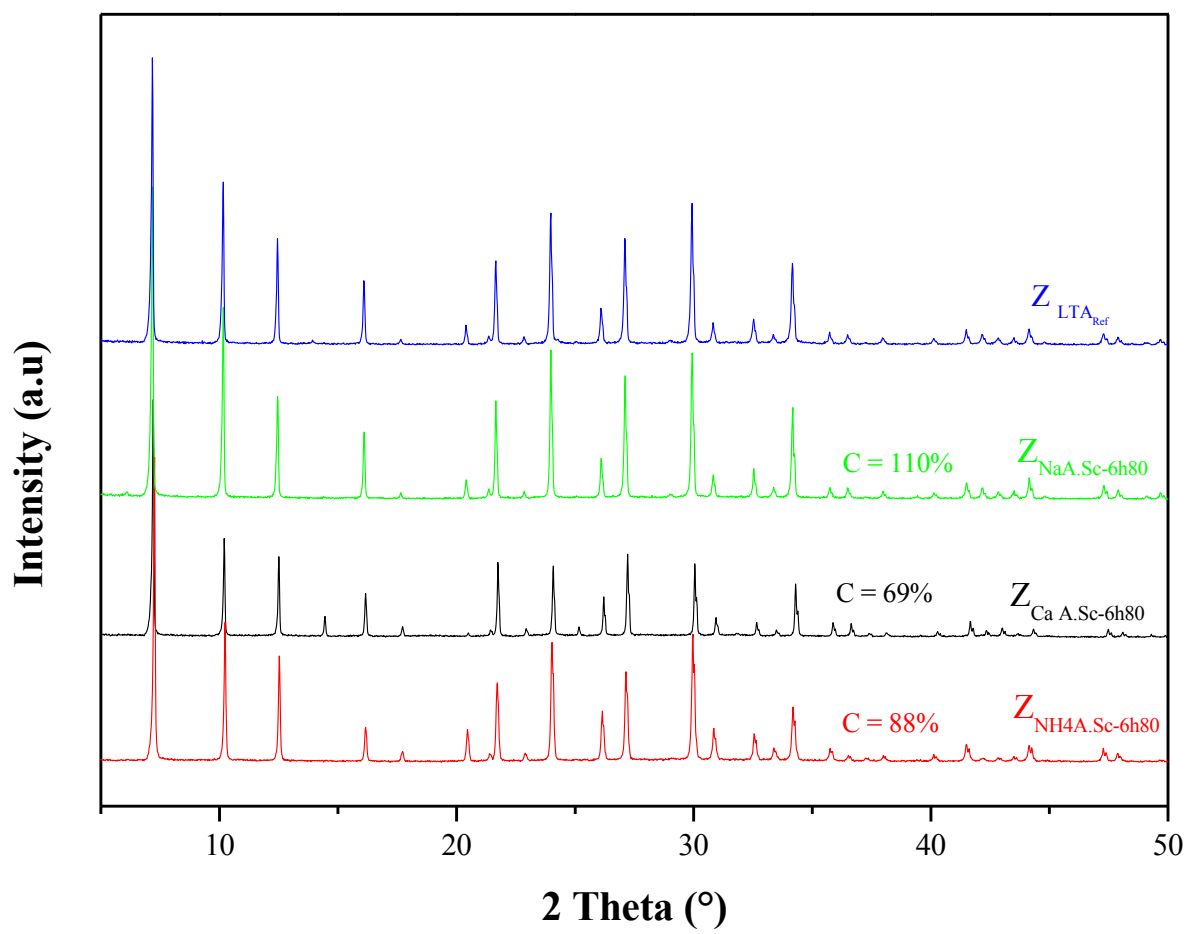


Figure 3
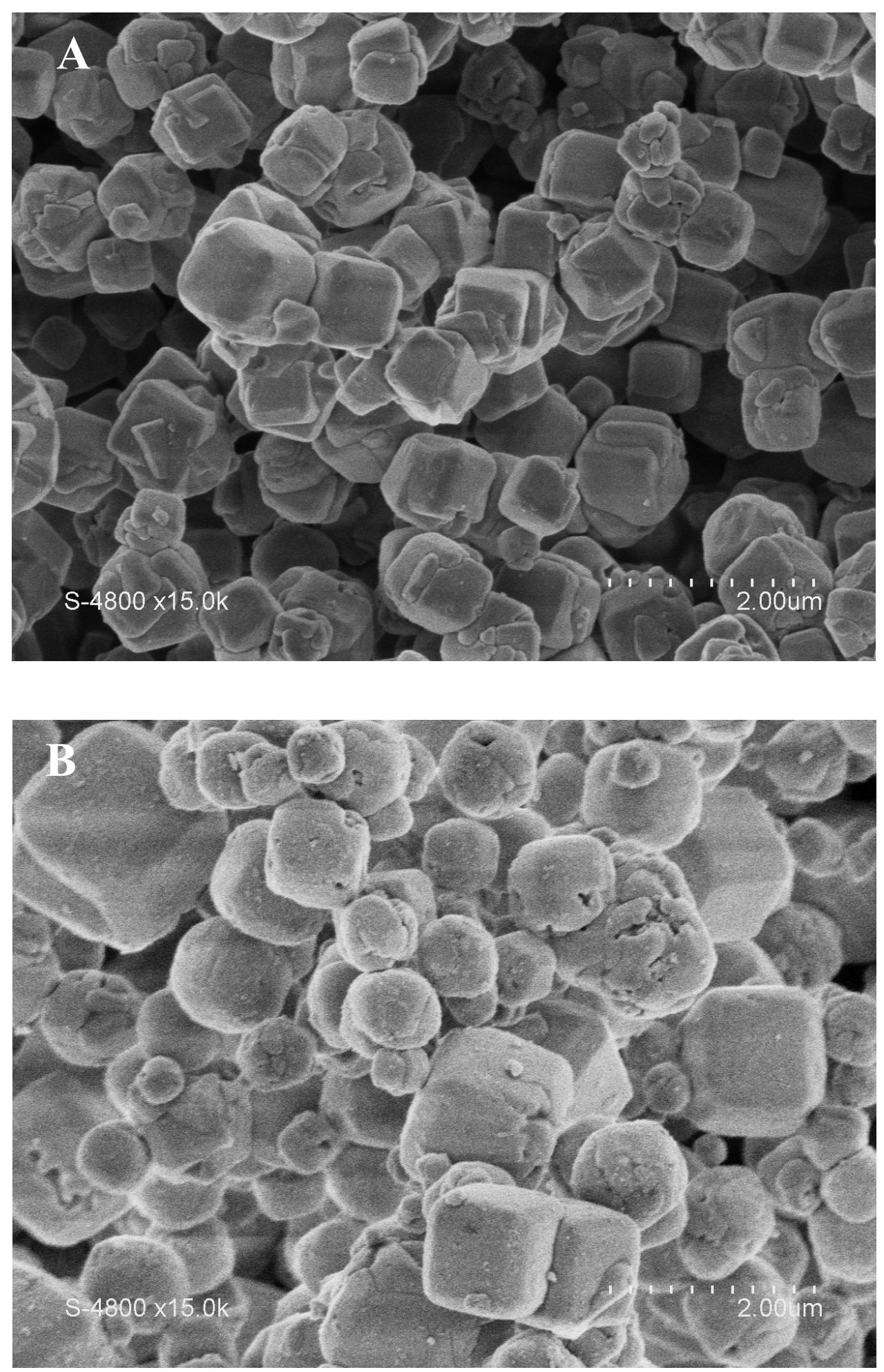


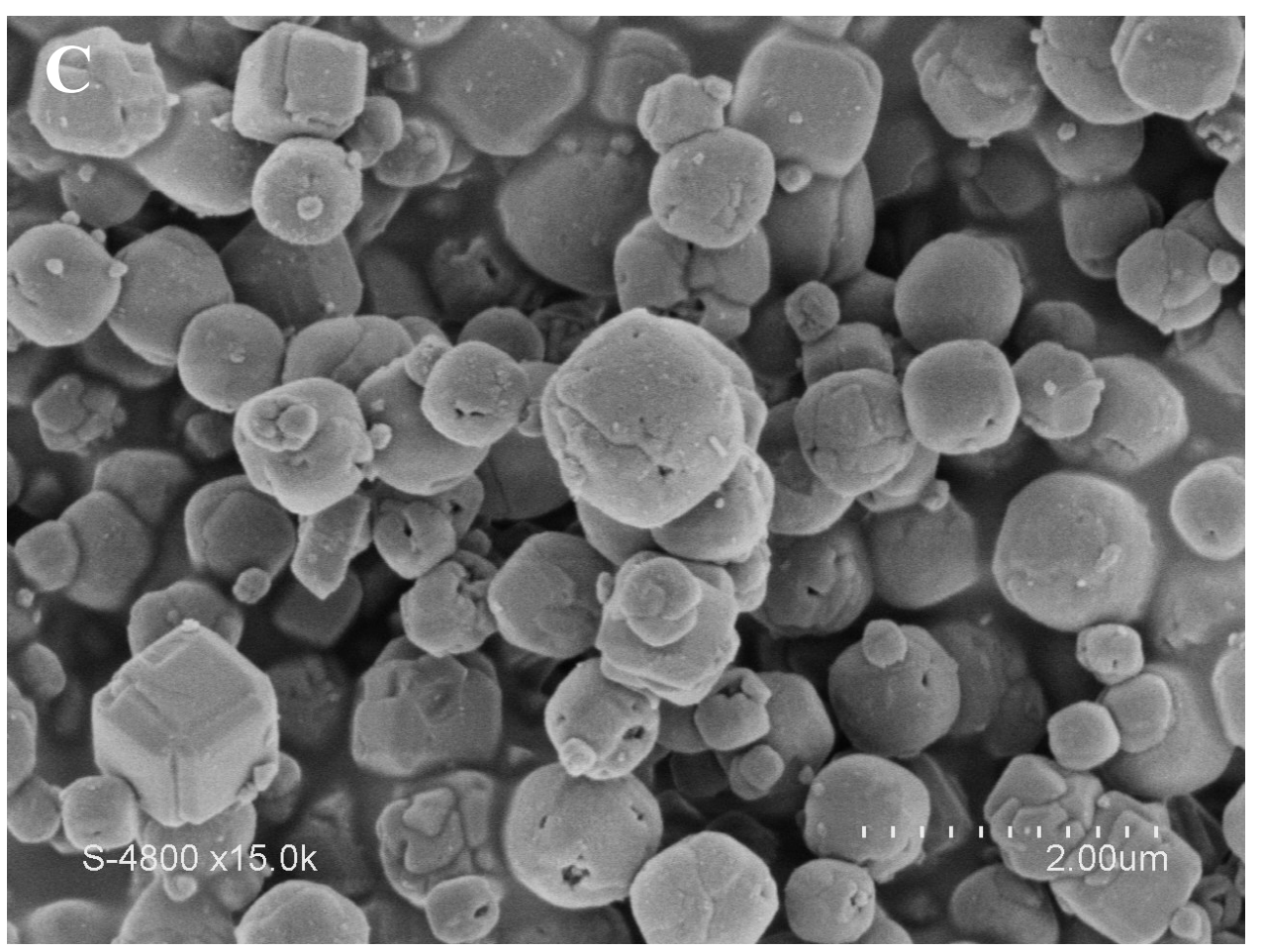




\section{Figure 4}

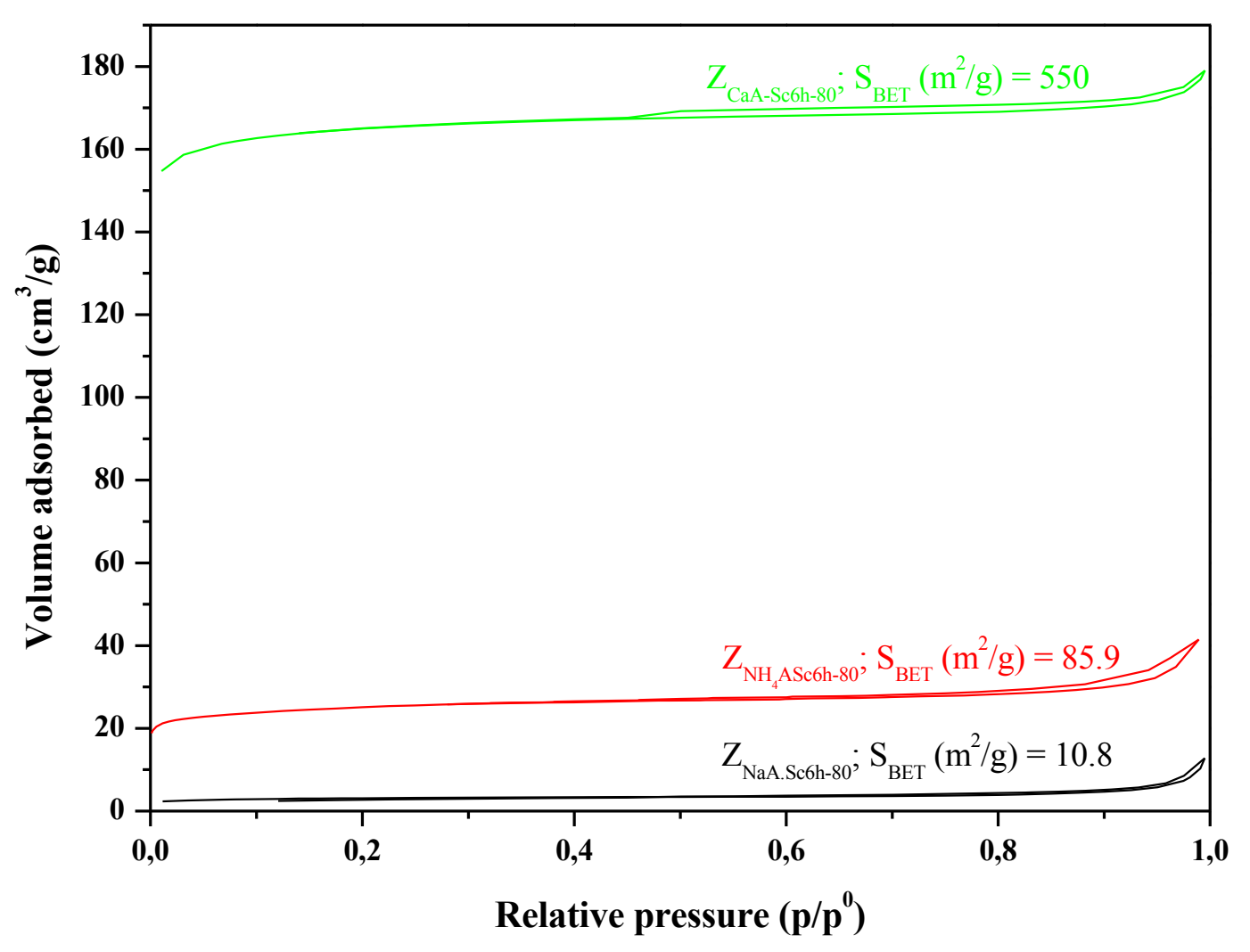


Figure 5

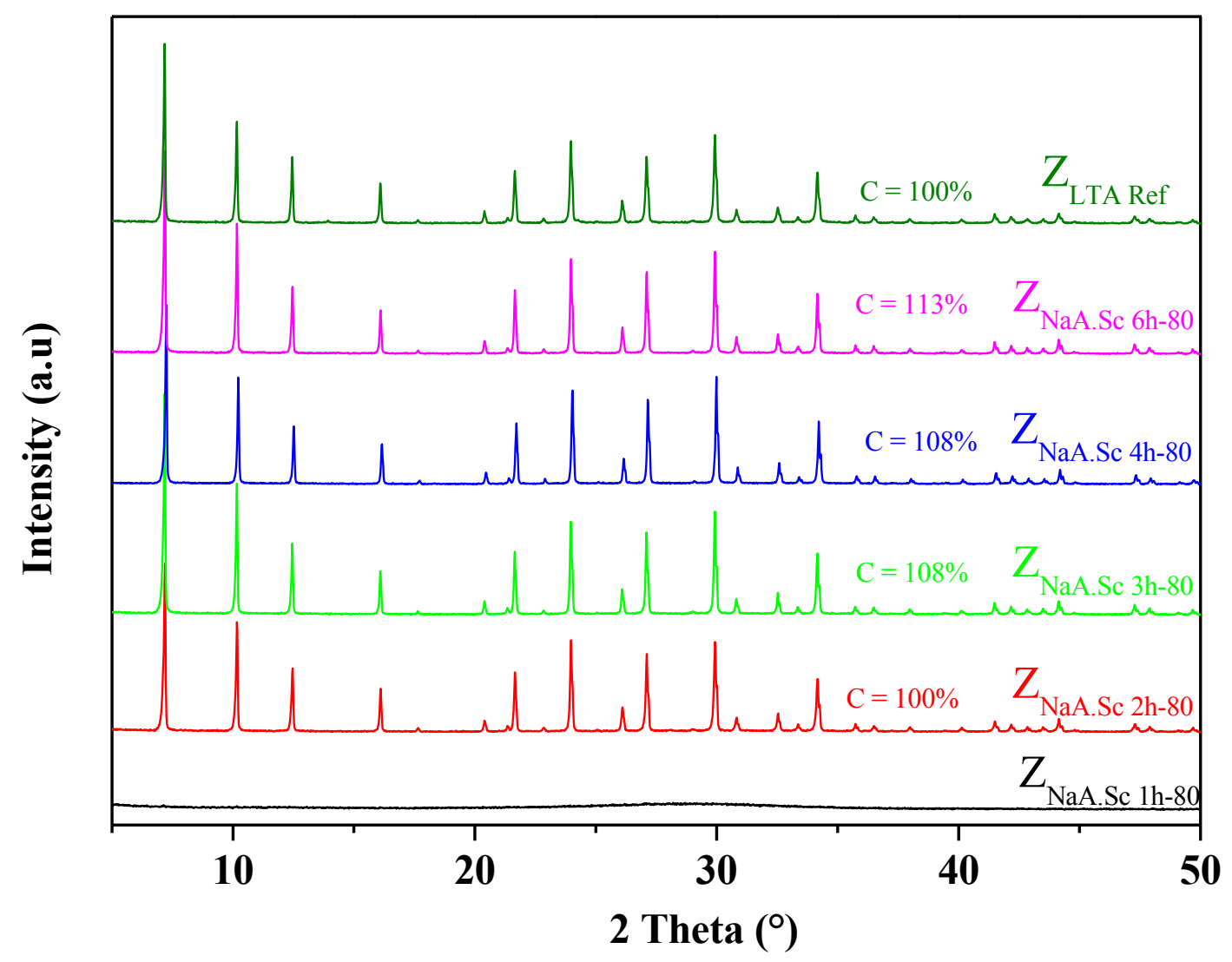

Erreur! Nous n'avons pas trouvé la source du renvoi. 
Figure 6

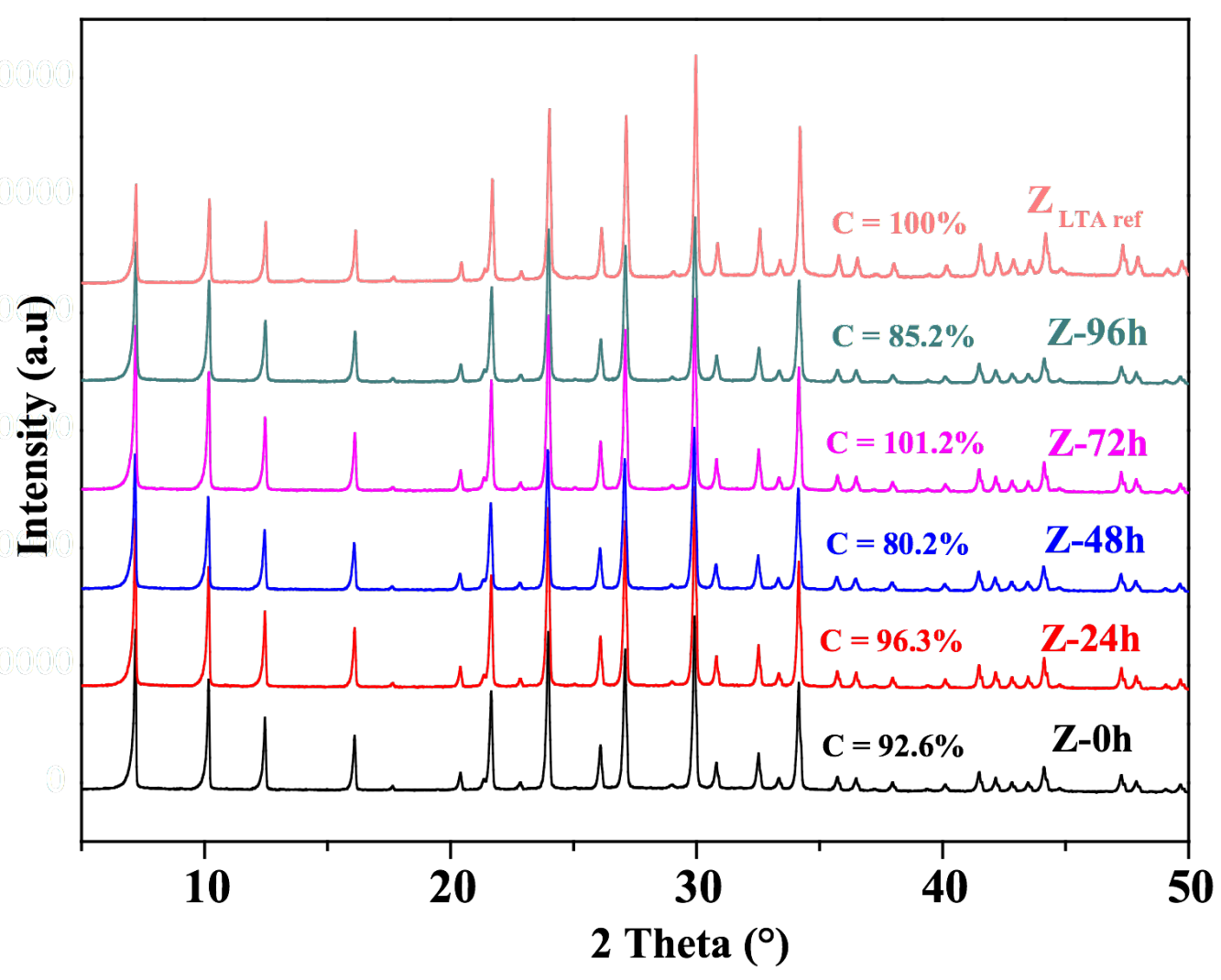


Figure 7
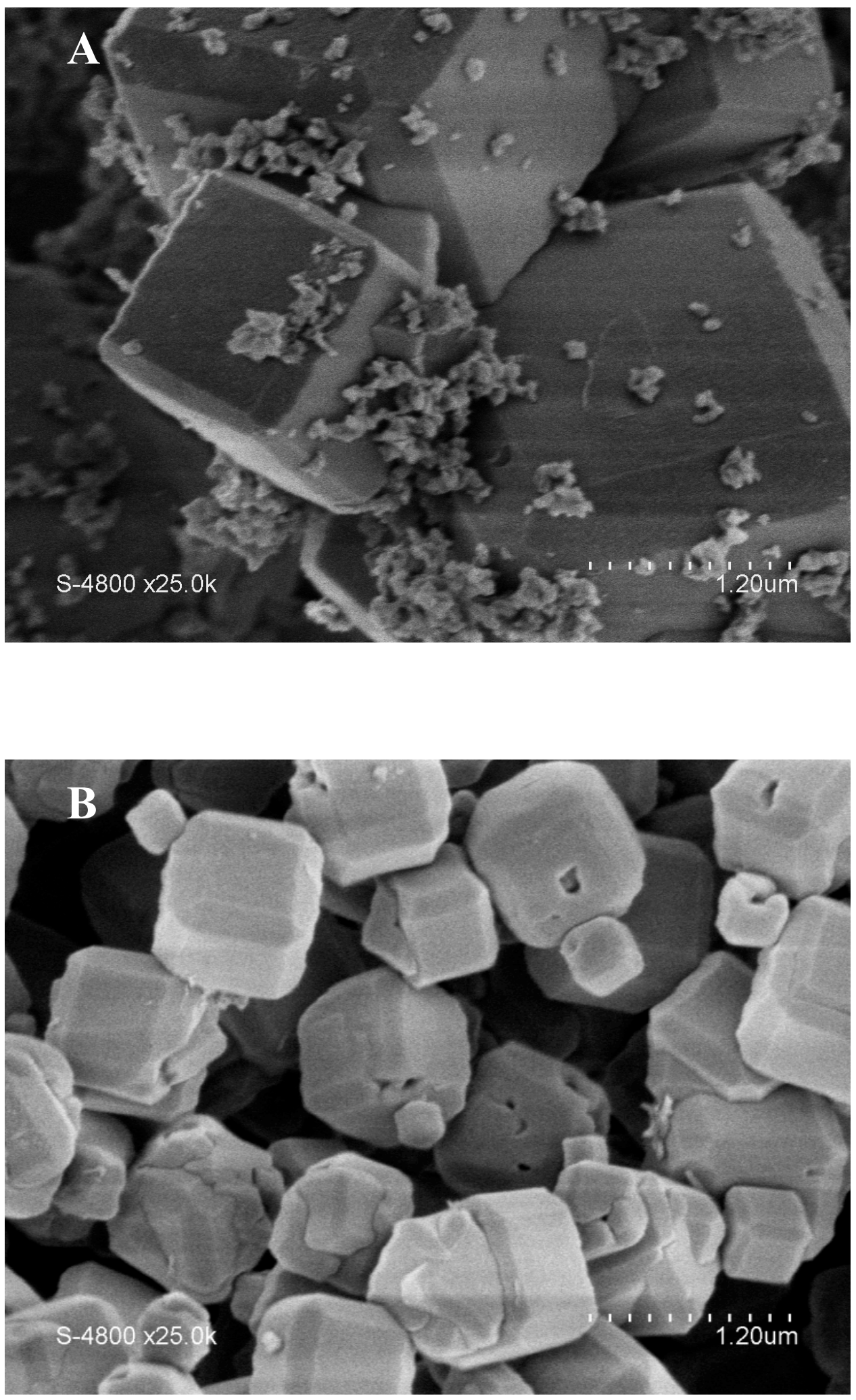


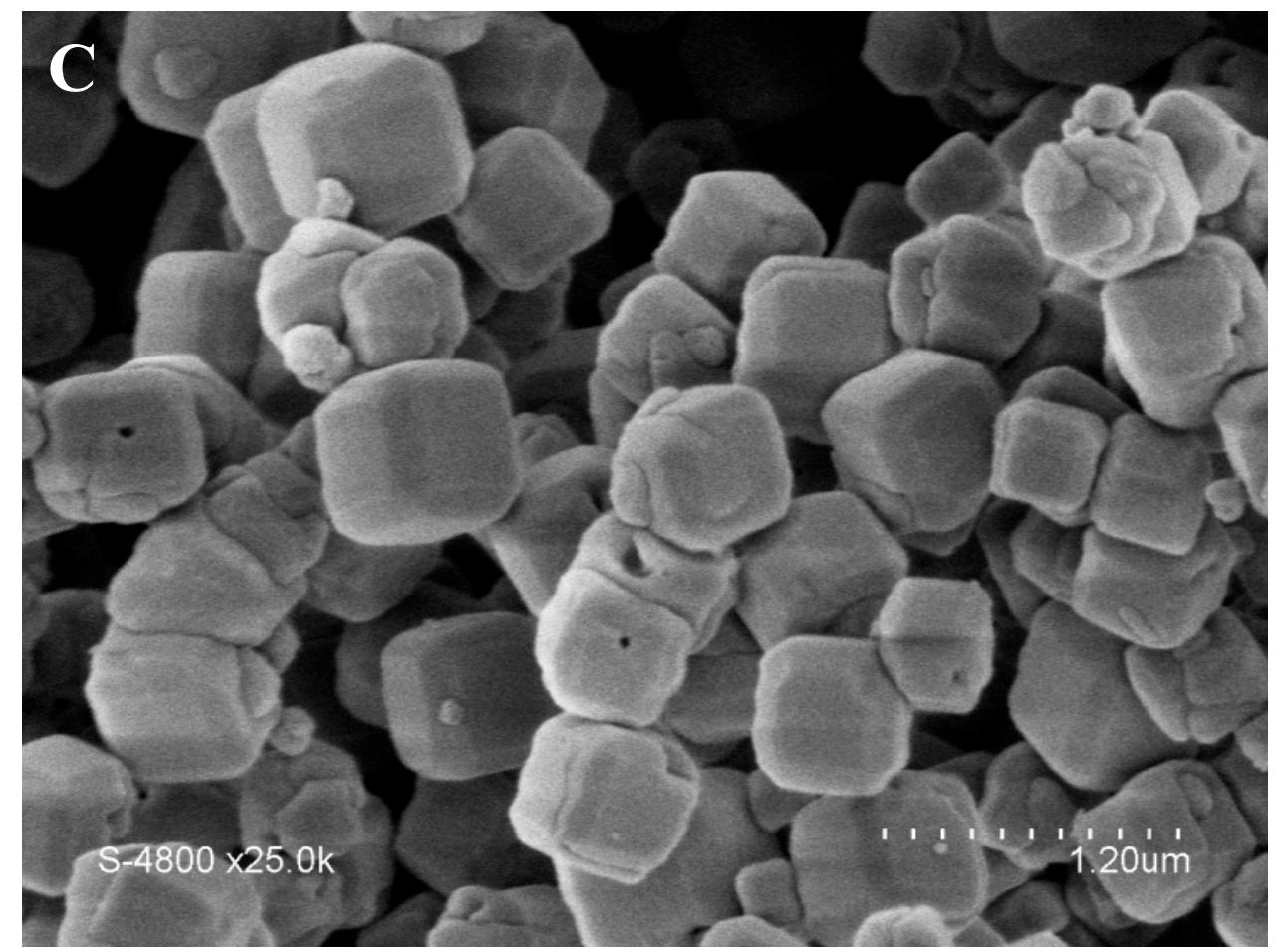


Figure 8

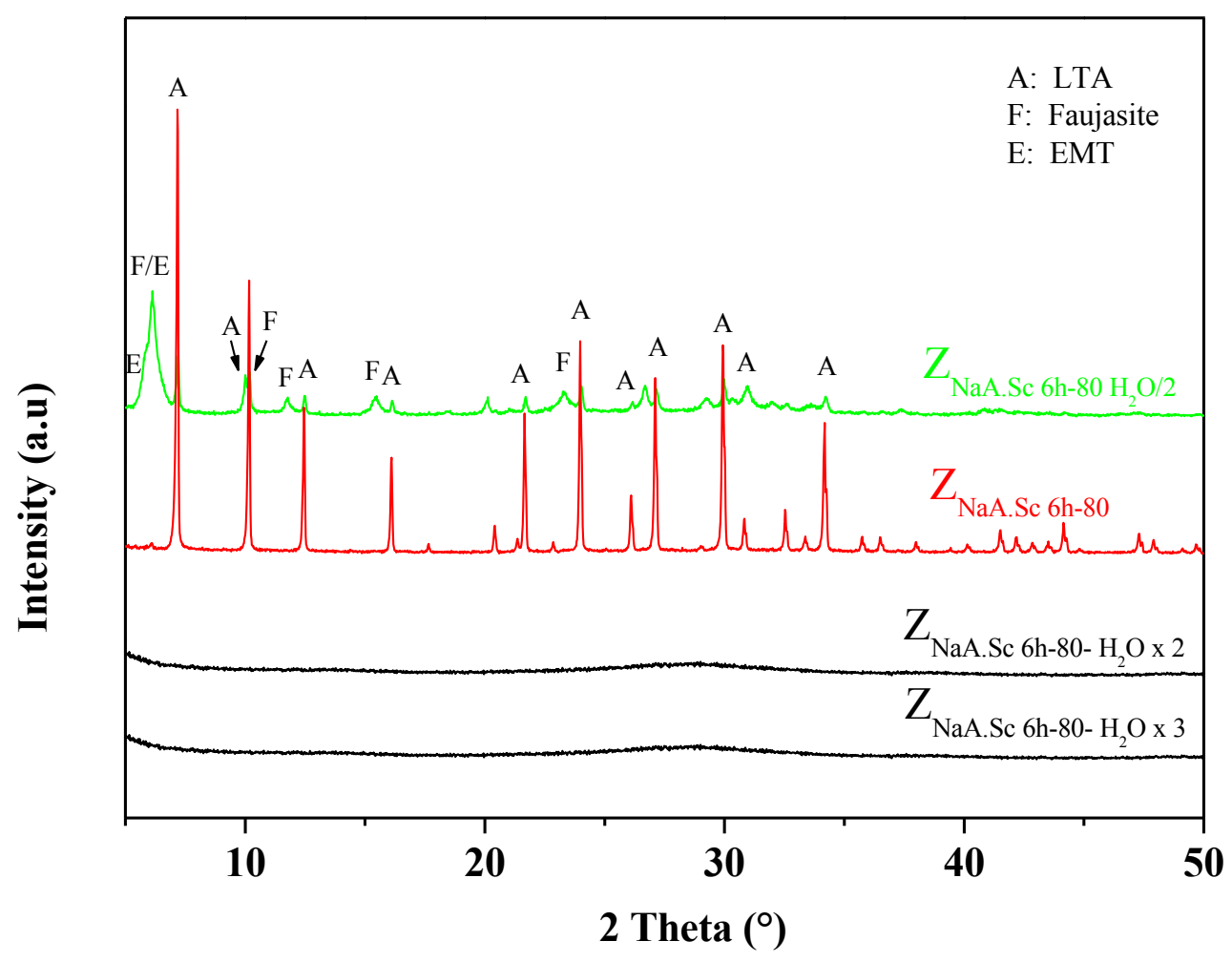




\section{Figure 9}

A: LTA

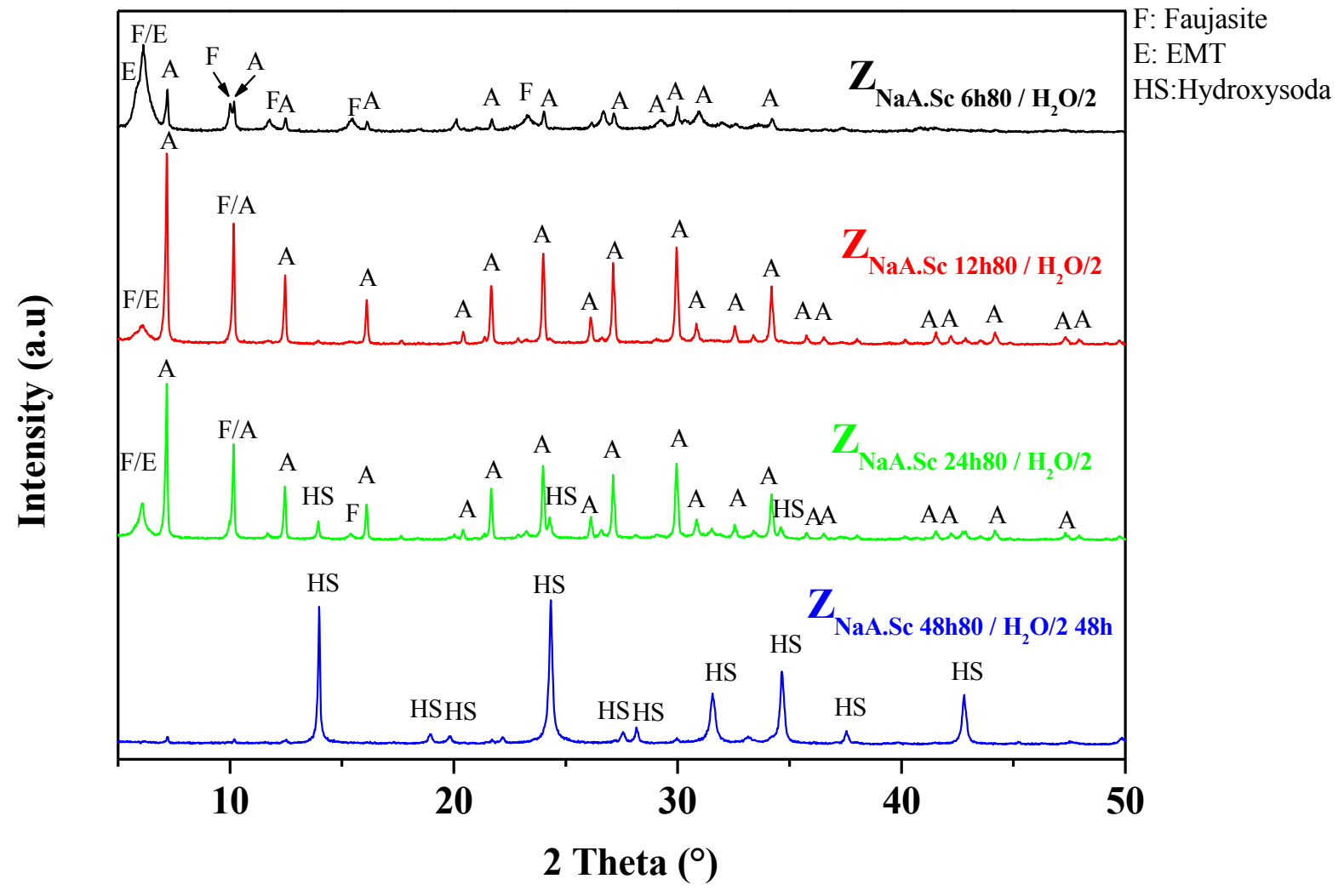


